\title{
Bipolar Plaka Akış Alanları Üzerine Deneysel Çalışmalar
}

\author{
${ }^{1}$ Nuri Furkan Koçak, ${ }^{* 2}$ Alparslan Topcu, ${ }^{3}$ Kadir Aydın, ${ }^{4}$ Selahattin Çelik, ${ }^{5}$ Merve Topcu
}

${ }^{1}$ Nallıhan Meslek Yüksekokulu, Elektronik ve Otomasyon Bölümü, Ankara Üniversitesi, Türkiye

${ }^{\text {*2} M u ̈ h e n d i s l i k ~ F a k u ̈ l t e s i, ~ M a k i n e ~ M u ̈ h e n d i s l i g ̆ i ~ B o ̈ l u ̈ m u ̈, ~ A d a n a ~ A l p a r s l a n ~ T u ̈ r k e s ̧ ~ B i l i m ~ v e ~ T e k n o l o j i ~ U ̈ n i v e r s i t e s i, ~}$ Türkiye

${ }^{3}$ Mühendislik Fakültesi, Makine Mühendisliği Bölümü, Çukurova Üniversitesi, Türkiye

${ }^{4}$ Mühendislik Fakültesi, Makine Mühendisliği Bölümü, Niğde Ömer Halisdemir Üniversitesi, Türkiye

${ }^{5}$ Teknik Bilimler Meslek Yüksekokulu, Mülkiyet Koruma ve Güvenlik Bölümü, Harran Üniversitesi, Türkiye

\section{Özet}

Temiz ve alternatif enerji arayışı, insanlı̆̆ın sürekli artan enerji talebini karşılama doğrultusunda artış göstermektedir. Yakıt pilleri, yakıtın kimyasal enerjisini kullanarak doğrudan elektriğe dönüştüren yüksek verimli enerji dönüşüm sistemleridir. Klasik elektrik enerjisi üretim çevriminde yakıt önce yakılarak 1sı enerjisi elde edilmekte, ardından buhar etkisi ile türbin döndürülmekte, jeneratörde akım elde edilmekte ve depolanmaktadır. Bu enerji dönüşümü oldukça karmaşık ve çok makineli bir sistem gerektirirken, her enerji dönüşümünde enerji kayıpları da meydana gelmektedir. Yakıt pillerinde ise sadece yakıtın elektronlarını devreden geçirerek yüksek elektriksel verimle enerji elde edilmektedir. $\mathrm{Bu}$ çalışmada yakıt pili çeşitlerinden PEM yakıt pilleri ele alınarak, PEM yakıt pillerinde kullanılan bipolar plakaların akış alanları incelenmiştir. Literatürde nümerik çalışmalar da bulunmakla birlikte, yakıt pillerinin oldukça değişken çalışma şartlarından dolayı deneysel olarak test etmek büyük önem arz etmektedir. Bu nedenle son on yılda yapılmış olan deneysel çalışmalar, yöntemleriyle sunulmuştur. Günümüzde çok popüler bazı akış kanalları verilmekle beraber, akış kanallarını birbirleriyle karşılaştırma yöntemiyle üstünlüğün belirlendiği anlaşılmış ve günümüzde hala optimum akış kanalına ulaşılamadığ̀ gözlemlenmiştir.

Anahtar Kelimeler: PEM yakıt pili, bipolar plaka, akış alanı, deneysel.

\section{Experimental Studies on Flow Fields of Bipolar Plate}

\begin{abstract}
Be in search of clean and alternative energy is increases with the increasing of energy demand of humanity. Fuel cells are high efficiency energy conversion systems that convert the fuel directly into electricity using the chemical energy of the fuel. In the classical electric power generation cycle, the first; fuel is burned and heat energy is obtained, then the turbine is turned with the effect of steam, after that current is obtained and stored in the generator. While this energy conversion requires a very complex and multi-machine system, energy losses occur with each energy conversion. In fuel cells, energy is obtained with high electrical efficiency using only electrons of the fuel. In this study, bipolar plate flow field was investigated used in PEM fuel cells. Although there are numerical studies in the literature, it is very important to test the fuel cells experimentally due to the highly variable operating conditions. For this reason, experimental studies in the last ten years were presented with their experimental approaches. Although some of the most popular flow channels are illustrated today, it is understood that superiority is determined by comparing the flow channels with each other and it is observed that the optimum flow channel is still not reached today.
\end{abstract}

Keywords: PEM fuel cell, bipolar plate, flow field, experimental.

*Sorumlu yazar: Alparslan TOPCU Adres: Mühendislik Fakültesi, Makine Mühendisliği Bölümü, Adana Alparslan Türkeş Bilim ve Teknoloji Üniversitesi, 01250, Adana, Türkiye. E-mail adresi: atopcu@atu.edu.tr, Phone: $+903224550000$ 


\section{Giriş}

Dünya'nın geleceği için enerji oldukça önemlidir ve sanayinin ve teknolojinin gelişmesi ile enerjiye ihtiyaç duyulmaktadır. Enerji kaynakları fosil yakıtlar, yenilenebilir kaynaklar ve nükleer kaynaklar olmak üzere üç kategoriye ayrılmaktadır [1]. Enerji ihtiyacının büyük oranı fosil kaynaklardan (ham petrol, linyit, doğal gaz vb.) karşılanmaktadır. Kullanılan fosil yakıtların yakılması ile salınan karbon dioksit, karbon monoksit, azot oksitler, metan ve kükürt dioksit gibi zararlı gazlar çeşitli çevre sorunlara yol açmaktadır. Bu nedenle fosil yakıtların yerine temiz enerji kaynaklarına ihtiyaç duyulmaktadır. Bu alternatif yakıtların başında güneş, rüzgâr, biyokütle, hidroelektrik ve hidrojen enerjisi gelmektedir. Hidrojen ile oksijenin reaksiyonundan türeyen elektrik enerjisinin elde edildiği sistemler yakıt pilleri olarak adlandırılmaktadır. Yakıt pilleri sürdürülebilir olması, hareketli parçaya ihtiyaç duymaması, sessiz olması, tasarımın kolay olması, çevreye zararsız emisyonlar oluşturmaması, artan enerji talebini karşılayabilecek olmasından dolayı fosil yakıtlı enerji sistemlerinin yerini alabilecek sistemlerdir.

Yakıt pilleri ilk olarak Sir William Robert Grove tarafından 1938 yılında yakıt hücrelerinin temel çalışma prensibi olan su elektrolizinin tersine çevrilmesiyle hidrojen ve oksijenden elektrik enerjisi üretmeyi başarmıştır. Grove hücresi olarak adlandırılan bu hücre 1,8 volt gerilim ve 12 amperlik akım üretmiştir [2]. NASA (Amerikan Ulusal Uzay Dairesi) reaktörlerin riskli olması, pil ve akülerin kısa ömürlü olmasından dolayı enerji kaynağı olarak yakıt pillerine yönelmiştir. İlk pratik yakıt hücreleri Apollo uzay programı için 1960'larda yapılmıştır ve günümüzde de uzay programlarında yakıt hücreleri kullanılmaktadır [3].

Yakıt pilleri sınıflandırılırken hücrenin içinde kullanılan elektrolit tipine göre sınıflandırılmaktadır. Bu sınıflandırmadaki yakıt pili tipleri ile ilgili temel bilgiler Tablo 1.1'te verilmiştir.

Tablo 1. Yakıt pili türlerinin karşılaştırılması [4]

\begin{tabular}{|c|c|c|c|c|c|c|}
\hline & PEM YP & $\begin{array}{l}\text { Doğrudan } \\
\text { Metanol YP }\end{array}$ & Alkali YP & $\begin{array}{c}\text { Fosforik } \\
\text { Asit YP }\end{array}$ & $\begin{array}{c}\text { Erimiş } \\
\text { Karbonat } \\
\text { YP }\end{array}$ & $\begin{array}{c}\text { Katı Oksit } \\
\text { YP }\end{array}$ \\
\hline Elektrolit & $\begin{array}{c}\text { Katı } \\
\text { polimer } \\
\text { membran }\end{array}$ & $\begin{array}{c}\text { Katı polimer } \\
\text { veya sivı } \\
\text { alkalin }\end{array}$ & $\mathrm{KOH}$ & $\begin{array}{l}\text { Siv1 fosforik } \\
\text { asit }\end{array}$ & $\begin{array}{l}\text { Sivı erimiş } \\
\text { karbonatlar }\end{array}$ & $\begin{array}{c}\mathrm{Y}_{2} \mathrm{O}_{3} \text { içeren } \\
\text { zirkonya }\end{array}$ \\
\hline $\begin{array}{c}\text { Çalışma } \\
\text { Sicaklığı } \\
\left({ }^{\circ} \mathrm{C}\right)\end{array}$ & 80 & $50-90$ & $65-220$ & $150-220$ & 650 & $600-1000$ \\
\hline Yakıt Tipi & $\mathrm{H}_{2}$ & Metanol & $\mathrm{H}_{2}$ & $\mathrm{H}_{2}$ & $\mathrm{CH}_{4}, \mathrm{H}_{2}, \mathrm{CO}$ & $\mathrm{CH}_{4}, \mathrm{H}_{2}, \mathrm{CO}$ \\
\hline Isı Yönetimi & Soğutucu & Soğutucu & $\begin{array}{l}\text { Soğutucu- } \\
\text { koj. }\end{array}$ & Kojenerasyon & Kojenerasyon & Kojenerasyon \\
\hline Verim & $\% 35-60$ & $\% 35-40$ & $\% 50-70$ & $\% 35-50$ & $\% 40-55$ & $\% 45-60$ \\
\hline
\end{tabular}

Yakıt pili türleri içerisinde polimer elektrolit membranlı (proton değişim membran, PEM) yakıt pili en popüler yakıt pili türüdür ve bu yakıt pili türünde genellikle yakıt olarak hidrojen kullanılmaktadır [4]. PEM yakıt pilleri diğer yakıt türlerine göre düşük çalışma sıcaklığına sahip olmasından dolayı daha hızlı devreye girmektedir [5]. Düşük çalışma sıcaklığından kaynaklanan 
yavaş reaksiyon oranı problemi, nitelikli katalizörler ve elektrotlar kullanılarak çözülmüştür [6]. PEM yakıt pilinin dezavantajları; yakıt olarak saf hidrojene ihtiyaç duyması, sisteminde pahalı platin katalizör bulundurması, hücre içerisinde biriken suyun yönetilme problemi, hızlı yük değişimlerine karşı olumsuz etkilenmesi gibi olumsuz yönleri de bulunmaktadır [7-8].

PEM yakıt pilini oluşturan temel elemanlar; PEM yakıt pilinin merkezinde membran elektrot grubu (MEG), sızdırmazlık contaları, membran elektrot atacının her iki yanında reaktant gazların taşınması ve hücrede dağılmasını sağlayan bipolar plakalar, akım toplayıcılar ve nihai (son) plakalar bulunmaktadır [9-11]. PEM hücresi oluşturan elemanlar Şekil 1'de gösterilmiştir.

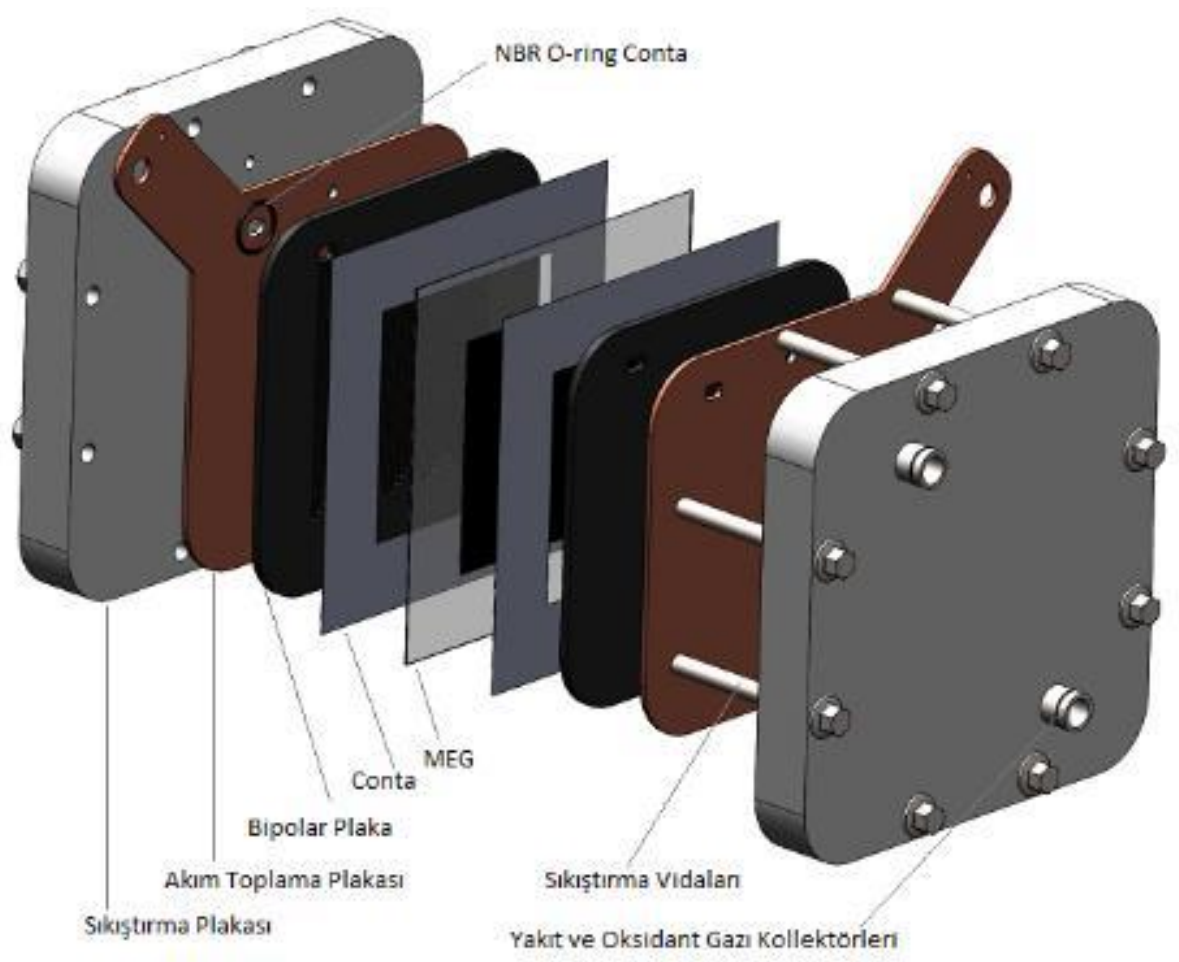

Şekil 1. PEM tipi yakıt hücresini oluşturan elemanlar [12]

PEM yakıt pilleri reaktant gazlarının kimyasal enerjisini doğrudan elektrik enerjisine dönüştürerek, yan ürün olarak su ve 1sı açığa çıkaran sistemlerdir. PEM yakıt hücresinde iki bipolar plaka arasında proton iletimi, proton iletken özelliğine sahip polimerik membran tarafından sağlanmaktadır. PEM yakıt pili çalışma prensibi Şekil 2' de gösterildiği gibi katot sürekli olarak hava veya $\mathrm{O}_{2}$ ile beslenirken anot ise sürekli $\mathrm{H}_{2}$ gazı ile beslenmektedir. Hidrojen yakıtı, anot tarafında katalize edilerek proton ve elektronlarına ayrılır. Burada elde edilen hidrojen protonları polimer elektrot membrandan geçerek katot tarafinda $\mathrm{O}_{2}$ ile buluşur ve reaksiyona girer ve bu reaksiyon sonucu ürün olarak su ve 1s1 elde edilir. Arada bulunan elektrolit zar pozitif iyonların anottan katoda akışını sağlayarak DC akımı oluşturmaktadır [13]. 


\section{Bipolar Plakalar}

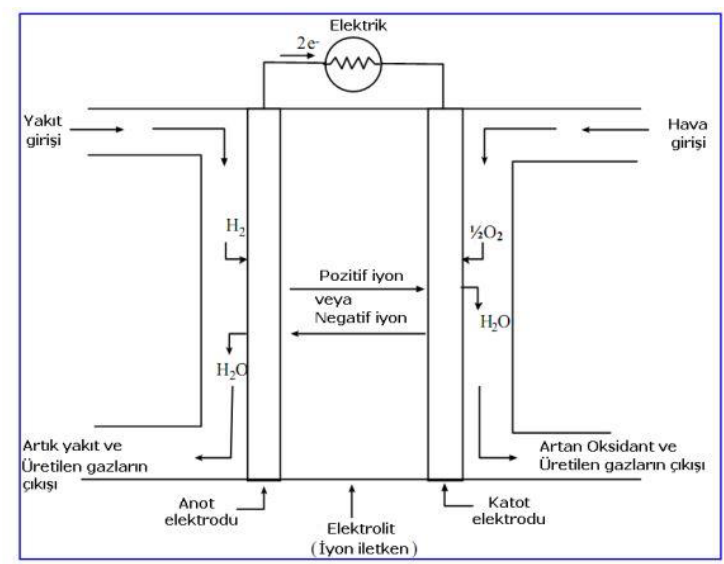

Şekil 2. PEM Yakıt pili çalışma prensibi [14]

Bipolar plakalar (BP) PEM yakıt hücresinin en önemli bileşenlerinden biridir. Yakıt hücreleri seri olarak birleştirildiğinde, akış plakalarının bir yüzeyinde anot gazı, diğer yüzeyinde ise katot gazı geçmektedir. Aynı plakanın üzerinde hem anot hem katot kutupları bulunduğu için "Bipolar Plaka" (Çift kutuplu plaka) olarak adlandırılmıştır. Bipolar plakalar yakıt pilinde bulunan reaktant ve oksidant gazların sisteme dağıtılmasını, reaksiyonlar sonucu oluşan gazların sistemden uzaklaştırılmasını sağlamaktadır. Yakıt pili staklarında hücreler arasındaki elektrik bağlantısının sağlanması ve elektronların sistemden çekilmesi bipolar plakalar ile gerçekleşmektedir [15-16]. Ayrıca bipolar plakalar yakıt pilinde elektrokimyasal reaksiyon sonucu açığa çıkan suyun yakıt pilinden uzaklaştııılmasını da sağlar [17]. Bipolar plakalar, gaz difüzyon tabakaları üzerindeki reaktant gazlarını homojen olarak dağıtmalı, yüksek elektriksel iletkenliğe sahip olmalı, asitli ve korozif ortam şartları nedeni ile yüksek korozyon direncine sahip olmalı, stak içerisinde hücrelerin birbirinden ayrılmasını sağlamalı ve gaz kaçaklarını engellemelidir [18]. Bipolar plakaların bu özellikleri yerine getirmesi için plaka üretiminde karbon kompozit polimerler, esnek grafit plakalar, metal levhalar, grafit gibi malzemeler tercih edilmektedir [19]. Bu malzemeler içerisinde şuana kadar en iyi performansı veren grafit malzeme grubu olmuştur. Grafit, oda sıcaklığında çok yüksek elektriksel iletkenliği ve yüksek korozyon direnci nedeniyle BP olarak sıklıkla tercih edilmektedir. Bunun yanında, mekanik dayanımının düşük olması ve yüksek maliyetli olması ise dezavantajları arasında bulunmaktadır.

Soğutma plakalarının bulunmadığı sistemlerde 1sıl yönetim bipolar plakalar tarafindan sağlanır. Isıl yönetim için plakanın malzemesi ve kanal tasarımı oldukça önemlidir. Kanal tasarımı, düz akış, serpantin akış, içten kolektörlü, içten nemlendirme ve içten soğutma vb. şekilde yapılmaktadır [12]. Ayrıca bipolar plakalarda reaktant gazların homojen olarak dağılması için de plaka tasarımı oldukça önemlidir. Çünkü plakaların verimli bir şekilde çalışması gaz akış kanallarındaki akış konfigürasyonuna bağlıdır [20]. Alt başlıklarda akış alanları ile ilgili detaylar sunulmuştur.

\section{Akış Alanları}

Yakıt pillerinin tümü aynı prensipte çalışmaktadır. Elektroliz olayının tersi olarak çalışan yakıt 
pili sisteminde, reaktantın elektronları elektrik enerjisi kaynağı olarak kullanılmakta, sonrasında reaktant ve oksidant birleşerek sistemi terk etmektedir. Sistemde hava ve hidrojen kullanılması durumunda ise atık ürün olarak sistemin çalışma sıcaklığına bağlı olacak şekilde su molekülü veya su buharı oluşmaktadır. Bu da yakıt pillerini son derece çevreci ve zararsız kılmaktadır. Akış alanları, reaktant ve oksidant gazların reaksiyon alanlarına ulaştırılması amacıyla kullanılmaktadır. Pek çok farklı akış alanı tasarımı olmakla birlikte, tüm yakıt pilleri için geçerli bir kural olarak; akış alanları verimsiz ve aktif bir şekilde kullanılamazsa, sistem verimi ve yakıt pili performansı düşmektedir. Bu nedenle araştırmacılar, akış alanları üzerine çok uzun yıllardır önem vermekte ve daha verimli akış alanı araştırmaları devam etmektedir. Şekil 3'te literatürde kullanılan bazı akış alanlarına örnekler sunulmuştur [1]. Akış alanları genellikle $1 \mathrm{~mm}$ genişlik ve $1 \mathrm{~mm}$ derinlik olacak şekilde üretilirler. Daha geniş ve daha derin veya daha dar ve daha yüksek olması durumunda da yapılan çalışmalar mevcuttur ve her bir akış alanının özellikleri farklı farklı olmaktadir.

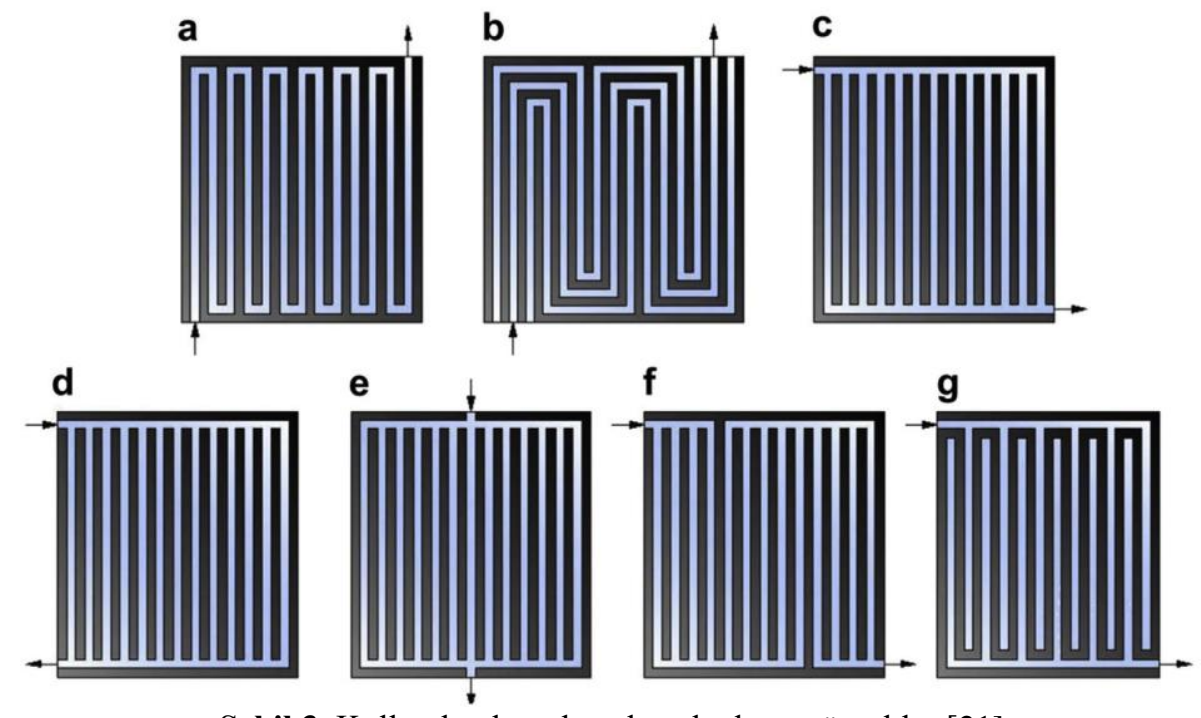

Şekil 3. Kullanılmakta olan akış alanlarına örnekler [21]

Akış alanları sadece bu şekilde gösterilmiş olan alanlarla sınırlı değildir. Çok farklı akış alanları da mevcuttur. Şekil 4'te farklı tip akış alanları gösterilmiştir [9]. Teknolojinin gelişmesiyle birlikte doğadaki bazı doğal tasarımlar simülasyon ortamına aktarılabilmekte ve bu tasarımlar baz alınarak bazı optimizasyonlar sağlanabilmektedir. Doğada bulunan yaprak damarlarının akış (su) yönetiminin iyi olduğu yaprak çeşitleri dahi, BP akış alanı olarak düşünülmüştür. 

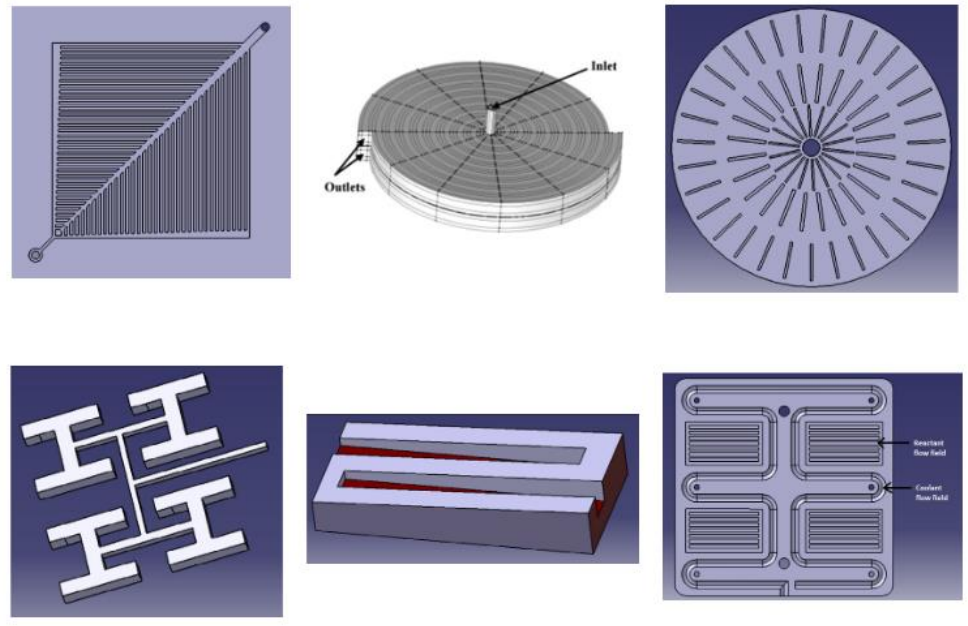

Şekil 4. Literatürde bulunan farklı tip akış alanları [9]

Çelik, akış alanının PEM yakıt pili performansına etkisini incelemiş̧tir [12]. Aynı test şartları altında farklı akış alanları kullanarak gerçekleştirdiği bu çalışmada karşılaştırdığı akış alanları, Şekil 5 'te sunulmuştur. Belirtilen akış alanları içerisinde Şekil 5(e)'de sunulan akış alanının, sabit nem ve sicaklık altında gerçekleştirilen testlerde en iyi sonucu verdiği belirtilmiştir.

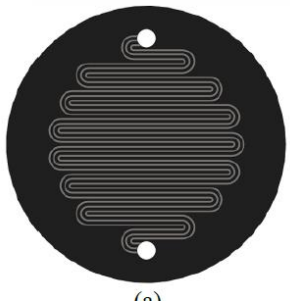

(a)

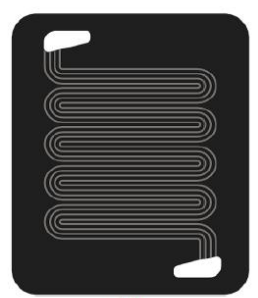

(d)
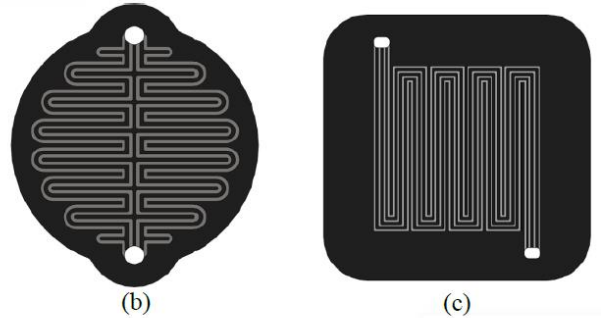

(c)

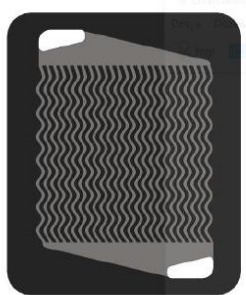

Şekil 5. Çelik'in deneysel çalışmasında kullandığı farklı akış alanları [12]

Dhahad vd., BP akış alanı üzerine deneysel bir çalışma gerçekleştirmişlerdir [22]. Tekli, ikili ve üçlü serpantin akış alanlarının kullanıldığı ve bunların akış dönüş noktalarının (dirsek) açılarının keskin ve geniş dönüşlü olarak karşılaştırıldığ1 çalışmada, kendilerinin önerdikleri akış alanı tipinin daha iyi performans verdiğini öne sürmüşlerdir. Akış alanlarının karşılaştırılması yöntemi, literatürde sıklıkla kullanılmakta olup, pek çok çalışma gerçekleştirilmiştir [23-30]. Awin ve Dukhan, serpantin akış alanına sahip klasik grafit BP ile alüminyum içine yerleştirilen alüminyum metal köpük BP'nin performanslarını karşılaştırmıştır [30]. Üç, dört farklı olay çalışması (case study) yaparak, bazı durumlarda grafitten daha iyi sonuç verdiğini belirtmişlerdir. Ayrıca yaklaşık \%28'lik bir ağırlık azalması sağladıklarını belirtmişlerdir. BP'lerin ağırlıklarının, 
stak ağırlığ̣ının çok büyük bir kısmını (yaklaşık \%80) oluşturduğunu düşünürsek, BP ağırlığını azaltmanın, sistemi hafifletmek adına çok yararlı olacağı açıktır.

\section{Deneysel Çalışma Düzeneği}

Yakıt pili çalışmalarında deneysel çalışma verileri büyük önem arz etmektedir. Günümüzde deneysel çalışmalarla birlikte analitik ve nümerik çalışmalar da gerçekleştirilebilmektedir. Deneysel çalışmalarda akış alanının görüntülenmesi zor olduğu için, araştırmacılar nümerik çalışmalarla akış alanlarını irdelemekte ve sonrasında deneysel analiz ile çalışmayı bütünleştirmektedirler [23,25,31,32]. Ancak yine de yakıt pillerinin deneysel şartlarda test edilmesi, gerçek çalışma koşullarının belirlenmesi açısından çok önemlidir. Deneysel sistemde ağırlıklı olarak yakıt pili test istasyonları kullanılır. Bu sistemler stabil çalışmaktadır ancak pahalıdırlar. Test istasyonuna sahip olmayan araştırmacılar kendi test düzeneklerini geliştirmektedirler. Örneğin Şekil 6'da sunulan test düzeneği Awin ve Dukhan [30] tarafindan oluşturulmuştur. Test düzeneklerinde daha önce kurulumu tamamlanmış ve test edilecek olan yakıt pili stağı bulunur. Bu stak içinde membran elektrot grubu (yakıt pili), sızdırmazlık elemanları, bipolar plakalar, akım toplayıcılar ve nihai (son) plakalar bulunur. Bu şekilde oluşturulmuş stağın görüntüsü Şekil 6'da sağ kısımda sunulmuştur. Aynı şeklin sol kısmı ise deneysel test kurulumunu temsil etmektedir. Stağa reaktant ve oksidant gazları sağlamak için yakıt ve hava tankları bulunur. Bu tanklardan çıkan uç, debimetreye (akışölçer) bağlanır ve stak içine gönderilen hava ve yakıtın debisi böylelikle bilinmiş olunur. Stağa gönderilen gazların ayrıca nemlendirilmeye ve sıcaklığa da ihtiyaçları vardır. Bu nedenle, eğer test düzeneğinde nemlendirme (şartlandırıcı) yoksa, bir tabla üzerine oturtulan cam kavanoza yakıt ve hava girişi bağlanabilir. Bu düzenek alttan 1sıtıldığı takdirde (istenilen sıcaklığa), sistemin dengeye gelmesi beklendikten sonra, hava ve yakıt stak içine gönderilebilir. Böylelikle hava ve yakıtın da nemlendirilmesi sağlanmış olur. Akım toplayıcılara bağlanan, aynı zamanda krokodil olarak adlandırılan kablolar ampermetre ve voltmetreye bağlanır. Böylece, stak içindeki reaksiyonlar sonucu sistemde oluşan akım ve volt değerleri gözlemlenebilir.
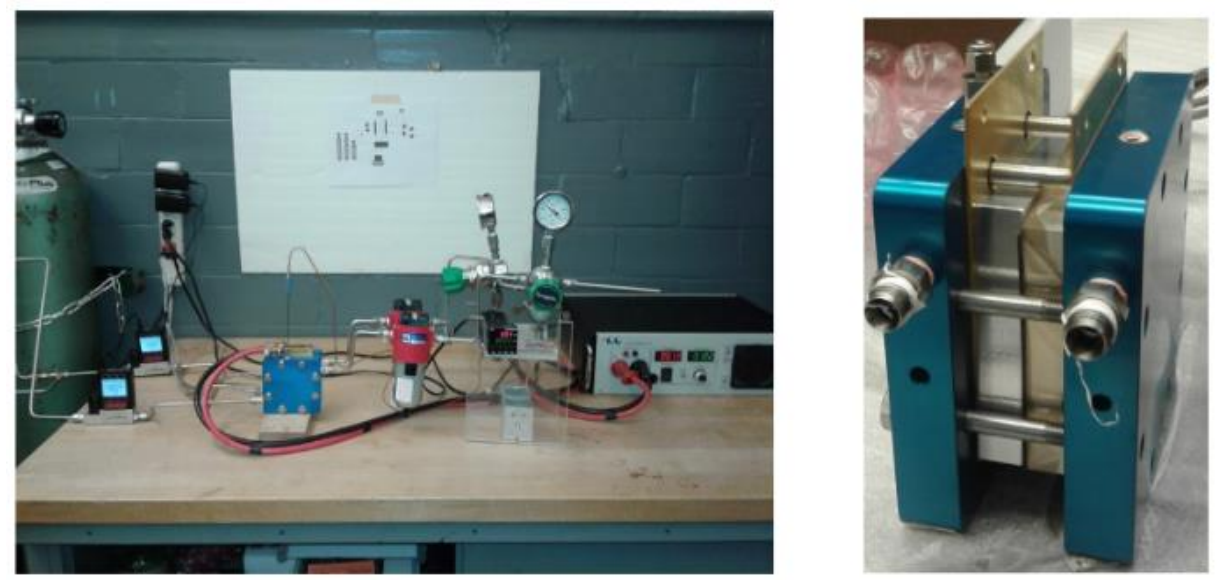

Şekil 6. Awin ve Dukhan'ın oluşturdukları yakıt pili test düzeneği [30]

Test düzeneği oluşturmak hem araştırmacıları yoran, hem de sistem içerisinde hata barındırabilen bir yapı oluşturmaktadır. Standart test istasyonu kullanmak ise büyük bir kolaylık olup, 
araştırmacılara daha net ve standart sonuçlar çıkarabilmektedir. Şekil 7'de Çelik'in deneysel akış alanı çalışmasını gerçekleştirdiği, test istasyonunu da kapsayan görsel sunulmuştur [12]. Burada hava ve yakıtın sıcaklık, nem ve debi kontrolü, sisteme yük verilmesi, oluşan volt ve amperin okunması, verilerin işlenmesi ve grafiklerin oluşturulması işlemlerinin tamamı test istasyonu ve bilgisayar yazılımları aracılığıyla sağlanmaktadır.

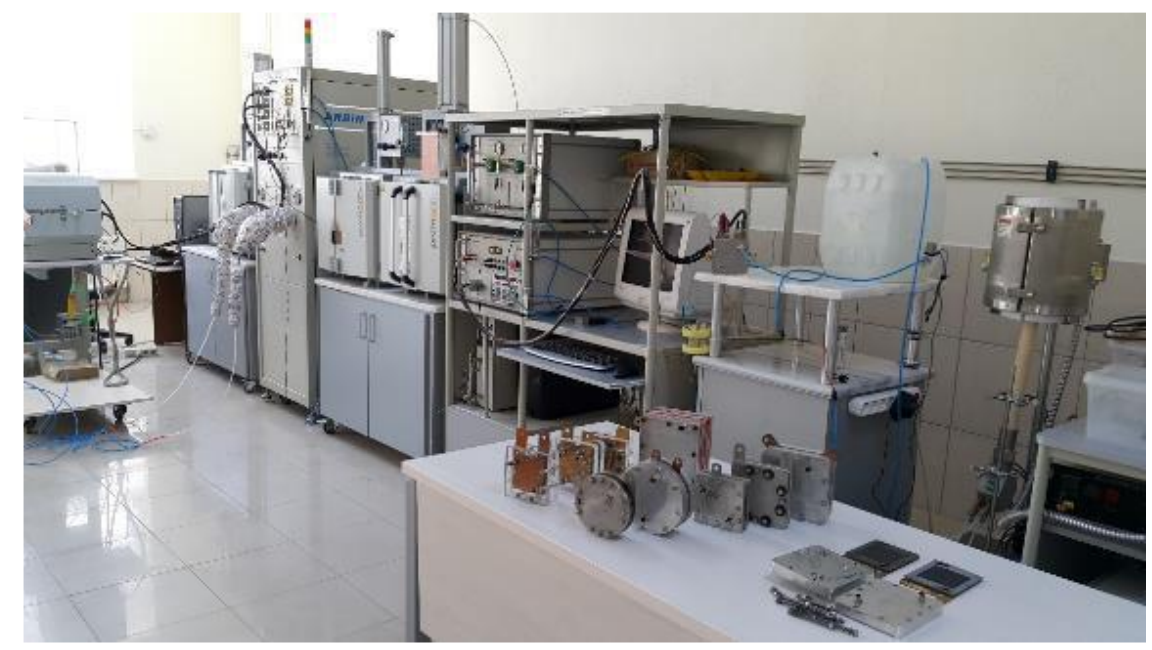

\section{Tartışma}

Şekil 7. Çelik’in test istasyonu kullanarak yaptığı deneysel çalışma [12]

Yakıt pilleri, özellikle otomotiv alanında elektrikli araçların piyasaya sürülmesiyle birlikte öne çıkmakta ve elektrikli araçların batarya düzenine alternatif bir sistem olarak değerlendirilmektedir. Bu çalışmada PEM yakıt pili bipolar plakaları akış alanları üzerine literatürde yapılan çalışmalar derlenmiştir. Literatürde var olan akış kanallarına paralel, serpantin, çoklu serpantin, grid, kaskad, spiral, birbirine geçmiş (interdigitated) gibi örnekler verilebilir. Akış alanı üzerine yapılan çalışmalar ağırlıklı olarak kıyaslama şeklinde gerçekleştirilmektedir. Genellikle karşılaştırılan akış alanlarının tüm özellikleri ve sınır şartları aynı tutularak, sadece akış alanı tipi değiştirilmekte ve aynı şartlar altında test edilmektedirler. Böylece plakaların birbirine göre üstünlükleri ve zayıf yanları belirlenebilmektedir. Akış plakaları giriş ve çıkış basınçları arasındaki farkın çok olması sistem performansını olumsuz etkilemektedir. Bu nedenle basınç farkının düşük olması avantajlı bir durumdur. Ayrıca akış alanının tamamının aktif bir şekilde kullanılması en önemli durumdur. Çünkü birçok akış alanında kör noktalar oluşmakta ve bu noktalara hidrojen ulaşamamaktadır. Bu durumda yakıt sarfiyatı artmakta ve performans düşüşü gözlemlenmektedir. Literatürdeki araştırmalarda çoklu kanallara sahip paralel akış alanının daha iyi performans gösterdiği belirtilmektedir. Yani yakıt ve havanın hücreye tek bir noktadan girip aynı yolu izleyerek sistemi terk etmesi değil, hücreye girip birçok kanala yayılarak dağılması amaçlanmaktadır. Böylece basınç farkı da azaltılmış olmaktadır. Şuana kadar yapılan çalışmalar birçok farklı alanın karşılaştırılmasını içerse de, en iyi akış alanını belirtmenin doğru olmadığı anlaşılmaktadır. Çünkü farklı yakıt pili sistemlerinde farklı akış alanlarının ticari olarak kullanıldı̆̆ı görülmektedir. 


\section{Kaynaklar}

[1] Karaca C. Mapping of energy potential through annual crop residues in Turkey. Int J Agr Biol Eng 2015;8(2):104-9.

[2] Gottesfeld S, Keller CF, Moller-Holst S, Redondo A. The human development report. Fuel Cells- Green Power, The United Nations, 1998.

[3] Yıldızbilir F. Yakıt pili ile elektrik enerjisi üretimi. MSc Thesis, Frrat University, Institute of Natural and Applied Science, 2006.

[4] Spiegel C. PEM fuel cell modeling and simulation using MATLAB. Elsevier Inc, 2008.

[5] De Bernardinis A, Frappé E, Bethoux O, Marchand C, Coquery G. Electrical architecture for high power segmented PEM fuel cell in vehicle application. IEEE, 2012;15-22.

[6] Ural BZ. Evsel yükler için yakit pili-güneş pili hibrit sisteminin tasarımı, modellenmesi ve uygulanması. MSc Thesis, Firat University, Institute of Natural and Applied Science, 2014.

[7] Rakhtala SM, Ghaderi R, Ranjbar NA. Prolong the Stack Life of PEM fuel cell system via higher order sliding mode control. IEEE, 2011;13-18.

[8] Özdemir L. PEM tipi yakıt pili için yüksek kazançlı DA-DA dönüştürücü tasarımı ve benzetimi, MSc Thesis, Kahramanmaraş Sütçü İmam University, Institute of Natural and Applied Science, 2019.

[9] Kahraman H, Orhan MF. Flow field bipolar plates in a proton exchange membrane fuel cell: Analysis \& modeling. Energ Convers Manage 2017;133:363-84.

[10] Dur E, Cora ÖN, Koç M. Experimental investigations on the corrosion resistance characteristics of coated metallic bipolar plates for PEMFC. Int $\mathbf{J}$ Hydrogen Energy 2011;36:7162-73.

[11] Lee HE, Chung YS, Kim SS. Feasibility study on carbon-felt-reinforced thermoplastic composite materials for PEMFC bipolar plates. Compos Struct 2017;180:378-85.

[12] Çelik S. Akış kanalı tasarımının PEM yakıt pili performansına etkilerinin incelenmesi. Omer Halisdemir University J Eng Sci 2018;7(1):407-16.

[13] Berning T, Lu DM, Djilali N. Three-dimensional computational analysis of transport phenomena in a PEM fuel cell. J Power Sources, 2002;106:284-94.

[14] Dündar P. Katı oksit yakıt pili uygulamalarında kullanılmak üzere kompozit elektrolit sentezi üzerine çalışmalar. MSc Thesis, Süleyman Demirel University, Institute of Natural and Applied Science, 2018.

[15] Madadi F, Rezaeian A, Edris H, Zhiani M. Improving performance in PEMFC by applying different coatings to metallic bipolar plates. Mater Chem Phys 2019;238:1-10.

[16] Ben Jadi S, El Jaouhari A, Aouzal Z, El Guerraf A, Bouabdallaoui M, Wang R, Bazzaoui EA, Bazzaoui M. Electropolymerization and corrosion resistance of polypyrrole on nickel bipolar plate for PEM fuel cell application. Materials Today, https://doi.org/10.1016/j.matpr.2019.08.072 [Article in Press].

[17] Wang L, Husar A, Zhou T, Liu H. A parametric study of PEM fuel cell performances. Int J Hydrogen Energy 2003;28:1263-72.

[18] Yılmaz C. Bipolar plaka gaz akış desen tasarımının PEM yakıt pili performansına etkisi. MSc Thesis, Gazi University Institute of Natural and Applied Science, 2018.

[19] Middelman E, Kout W, Vogelaar B, Lenssen J, De Waal E. Bipolar plates for PEM fuel cells. J Power Sources 2003;118:44-46.

[20] Pantea D, Darmstadt H, Kaliaguine S, Summchen, Roy C. Electrical conductivity of 
thermal carbon blacks: Influence of surface chemistry. Carbon 2001;39:1147-58.

[21] Wilberforce T, El Hassan Zaki, Ogungbemi E, Ijaodola O, Khatib FN, Durrant A, Thompson J, Baroutaji A, Olabi AG. A comprehensive study of the effect of bipolar plate (BP) geometry design on the performance of proton exchange membrane (PEM) fuel cells. Renew Sust Energ Rev 2019;111:236-60.

[22] Dhahad HA, Alawee WH, Hassan AK. Experimental study of the effect of flow field design to PEM fuel cells performance. Renew Energ Focus 2019;30:71-77.

[23] Ebrahimzadeh AA, Khazaee I, Fasihfar A. Experimental and numerical investigation og obstacle effect on the performance of PEM fuel cell. Int J Heat Mass Trans 2019;141:891904.

[24] Zhang X, Chen S, Xia Z, Zhang X, Liu H. Performance enhcancements of PEM fuel cells with narrower outlet channels in interdigitated flow field. Energ Procedia 2019;158:141217.

[25] Penga Ž, Bergbreiter C, Barbir F, Scholta J. Numerical and experimental analysis of liquid water distribution in PEM fuel cells. Energ Conv Manag 2019;189:167-83.

[26] Kang HC, Jum KM, Sohn YJ . Performance of unit PEM fuel cells with a leaf-veinsimulating flow field-patterned bipolar plate. Int J Hydrogen Energy 2019;44:24036-42.

[27] Kahveci EE, Taymaz I. Experimental study on performance evaluation of PEM fuel cell by coating bipolar plate with materials having different contact angle. Fuel 2019;253:12741281.

[28] Seyhan M, Akansu YE. The effect of a novel spark-plug plasma synthetic jet actuator on the performance of a PEM fuel cell. Int J Heat Mass Trans 2019;140:147-51.

[29] Kerkoub Y, Benzaoui A, Haddad F, Ziari YK. Channel to rib width ratio influence with various flow field designs on performance of PEM fuel cell. Energ Conv Manag 2018;174:260-75.

[30] Awin Y, Dukhan N. Experimental performance assessment of metal-foam flow fields for proton exchange membrane fuel cells. Appl Energ 2019;252:1-8.

[31] Ashrafi M, Kanani H, Shams M. Numerical and experimental study of two-phase flow uniformity in channels of parallel PEM fuel cells with modified Z-type flow-fields. Energy 2018;147:317-28.

[32] Chowdhury MZ, Timurkutluk B. Transport phenomena of convergent and divergent serpentine flow fields for PEMFC. Energy 2018;161:104-117. 